\title{
PENGARUH PENGGUNAAN PATI KULIT NANAS (Ananas comosus (L.) Merr.) SEBAGAI BAHAN PENGIKAT PADA GRANUL CTM
}

\author{
Tekla Kalalo ${ }^{1)}$, Paulina V.Y. Yamlean ${ }^{1)}$, Gayatri Citraningtyas ${ }^{1)}$ \\ ${ }^{1)}$ Program Studi Farmasi FMIPA UNSRAT Manado, 95115
}

\begin{abstract}
The biggest component found in pineapple peel are water and starch. One of the excipient that usually used in granule is starch that can used as disintegrant, filler and binder. This study aims to formulate and evaluate granule preparations with Pineapple peel starch binder at concentration of 4\%, 6\%, 8\% and 10\%. The Pineapple peel dried with oven and then mashed up with blender and precipitated in water until obtained starch. The Pineapple peel starch made as a binder in four formulations of granule based on different concentrate of Pineapple peel starch, they are F I 4\%, F II 6\%, F III 8\% and F IV 10\%. The Granules made by method of wet granulation by adding binder solution of pineapple peel starch to four formulations, and then dried and evaluated. The result evaluation of organoleptic gave the best result in formula III and IV, flow time of each formula has time a flow time that not too far different, 5.04-5.57 seconds, angle of repose in formula I-IV meet the requirements and formed the smallest angle in formula I $28^{\circ}$, real density of each formula about $1.09-1.82 \mathrm{~g} / \mathrm{ml}$ and meet the requirements because they are bigger than water density, while the moisture content and loss on drying doesn't meet the requirements because has high water content. The conclusion is Pineapple peel starch can't be used as a binder in CTM granule.
\end{abstract}

Keywords : Pineapple, Starch, Binder, Granules, Wet Granulation

\begin{abstract}
ABSTRAK
Komponen terbesar yang terdapat dalam kulit Nanas ialah air dan pati. Salah satu bahan tambahan yang sering digunakan dalam pembuatan granul ialah pati yang dapat berfungsi sebagai bahan penghancur, bahan pengisi dan bahan pengikat. Penelitian ini bertujuan untuk memformulasikan dan mengevaluasi sediaan granul CTM dengan bahan pengikat pati kulit Nanas pada konsentrasi 4\%, 6\%, $8 \%$ dan $10 \%$. Kulit nanas dikeringkan dengan oven kemudian dihaluskan dengan blender dan diendapkan dalam air sampai diperoleh butiran pati. Pati kulit Nanas dibuat sebagai bahan pengikat pada empat formulasi granul berdasarkan konsentrasi pati kulit Nanas yang berbeda yaitu F I 4\%, F II 6\%, F III 8\% dan F IV 10\%. Granul dibuat dengan metode granulasi basah yaitu dengan menambahkan larutan pengikat pati kulit Nanas pada empat formulasi, kemudian dikeringkan dan dievaluasi. Hasil evaluasi organoleptis memberikan hasil terbaik pada formula III dan IV, waktu alir dari tiap formula memiliki waktu yang tidak jauh berbeda yaitu 5,04-5,57 detik, sudut diam pada formula I-IV memenuhi persyaratan dan membentuk sudut terkecil pada formula I yaitu $28^{\circ}$, BJ sejati dari tiap formula berkisar dari 1,09-1,82 $\mathrm{g} / \mathrm{ml}$ sehingga memenuhi persyaratan karena lebih besar dari BJ air, porositas dari formulasi I-IV memenuhi persyaratan yang memiliki range 46\%-67,4\%, sedangkan pada kandungan lembab dan kadar air tidak memenuhi persyaratan karena memiliki kandungan air yang terlalu tinggi. Kesimpulannya pati kulit Nanas tidak dapat digunakan sebagai bahan pengikat pada granul CTM.
\end{abstract}

Kata Kunci : Nanas, Pati, Bahan Pengikat, Granul, Granulasi Basah 


\section{PENDAHULUAN}

Sedian-sediaan farmasi yang beredar merupakan suatu sistem yang kompleks, dimana terdiri dari banyak komponen termasuk zat aktif dari sediaan tersebut. Penambahan komponen tersebut bersamaan dengan komponen zat aktif bertujuan untuk melindungi zat aktif, meningkatkan stabilitas dari zat aktif dan meningkatkan keamanan dan efektifitas dari sediaan itu sendiri (Pawar, 2015).

Bahan tambahan yang memiliki peran penting dalam pembuatan granul ialah bahan pengikat atau binder. Pengikat dapat memperbaiki kerapuhan serta kekuatan granul dan tablet dan membentuk granul atau menaikkan kekompakan kohesi bagi tablet sehingga dapat meningkatkan kualitas tablet yang dihasilkan. Bahan pengikat yang berasal dari polimer sintetik ialah gelatin, selulose dan mikrokristalin. Selain berasal dari sintetik, binder dapat berasal dari alam seperti amilum manihot, amilum jagung dan ekstrak tumbuhan yang dijadikan gum (Sugiyono, dkk 2013).

Eksipien polimer alam yang sering digunakan sebagai bahan pengikat dalam pembuatan tablet adalah pati. Pati yang umumnya digunakan adalah pati singkong, jagung, gandum, kentang dan beras. Beberapa penelitian yang menggunakan pati sebagai bahan pengikat diantaranya penelitian oleh (Jufri dkk, 2006) tentang Penggunaan pati biji durian yang dapat digunakan sebagai bahan pengikat pada tablet ketoprofen secara granulasi basah dan penelitian yang dilakukan oleh (Sapri dkk, 2012) tentang penggunaan pati biji campedak yang menyimpulkan bahwa pati biji cempedak dapat digunakan sebagai bahan pengikat dalam pembuatan tablet parasetamol secara granulasi basah.

Penelitian ini menggunakan pati kulit Nanas sebagai bahan pengikat pada sediaan granul dengan zat aktif CTM. Kulit Nanas bersifat non toksik dan mengandung air dan karbohidrat yang besar. Karbohidrat yang terdapat dalam kulit Nanas berbentuk pati (Rahmawati, 2010). Kandungan pati yang ada dalam kulit Nanas memungkinkan untuk dimanfaatkan sebagai bahan baku, salah satunya digunakan sebagai bahan pengikat pada sediaan granul di bidang farmasi (Sidhatra, 1989), selain itu pemanfaatan limbah kulit nanas sebagai bahan tambahan pada sediaan farmasi juga dapat mengurangi pencemaran lingkungan sehingga hal tersebut melatarbelakangi terlaksananya penelitian tentang pembuatan granul dengan pati kulit Nanas sebagai bahan pengikat.

\section{METODE PENELITIAN}

Alat dan Bahan

Alat yang digunakan dalam penelitian ialah blender (Philips), timbangan analitik (aeADAM ${ }^{\circledR}$ ), aluminium foil, oven (Ecocell), corong gelas, lumpang, alu, statif, kertas grafik, mistar, ayakan 200 mesh, ayakan 14 mesh dan alat-alat gelas (Pyrex).

Bahan yang digunakan dalam penelitian ini ialah kulit Nanas, zat aktif CTM, laktosa, explotab, talk, magnesium stearat dan akuades.

\section{Prosedur Penelitian}

\section{Pengambilan Sampel}


Sampel yang digunakan dalam penelitian ini yaitu kulit Nanas yang didapatkan dari daerah Kotamobagu.

\section{Preparasi Sampel}

Kulit Nanas dipilih yang matang dan segar, dikupas kulitnya dan dicuci dari kotoran (tanah) dengan air mengalir hingga bersih. Kulit nanas dipotong tipis-tipis dengan pisau kemudian segera direndam dalam larutan garam dapur selama kurang lebih 10. Kulit Nanas dikeringkan dengan oven pada suhu $40^{\circ} \mathrm{C}$. Kulit Nanas yang sudah kering diblender hingga halus kemudian ditambahkan air dan disaring dengan ayakan 200 mesh. Fase cair yang mengandung pati dibiarkan untuk mengendap selama 6 jam hingga diperoleh butiran pati. Endapan pati yang didapatkan dibilas sebanyak 3 kali dengan akuades. Endapan pati yang telah dibilas dikeringkan dalam oven pada suhu $40^{\circ} \mathrm{C}$ hingga kering.

\section{Pengujian Kualitatif Pati}

Pati kulit Nanas sebanyak 2 gram ditetesi akuades secukupnya dan ditambahkan dengan iodin sebanyak 5-10 tetes. Perubahan warna yang terjadi diamati,

\section{Preparasi Larutan Pengikat}

Larutan pengikat dibuat dengan konsentrasi masing-masing yaitu 4\%,6\%,8\% dan $10 \%$ (b/v). Akuades disiapkan sebanyak $100 \mathrm{ml}$, selanjutnya pati yang telah ditimbang masing-masing disuspensikan dengan air dingin $30 \mathrm{ml}$ di wadah gelas. Sementara itu, didihkan akuades secukupnya. Aquades mendidih sebanyak 70 ml dimasukkan ke dalam suspensi pati awal hingga volume $100 \mathrm{ml}$, diaduk hingga terbentuk larutan pati.

\section{Formulasi Granul}

Granul dibuat 125 gram per

\begin{tabular}{ccccc} 
formulasi & dengan & \multicolumn{2}{c}{ konsentrasi } & bahan \\
\hline BAHAN & F I & F II & F III & F IV \\
\hline CTM (mg) & 4 & 4 & 4 & 4 \\
Pati kulit & 4 & 6 & 8 & 10 \\
$\begin{array}{c}\text { Nanas (\%) } \\
\text { Explotab }\end{array}$ & 4 & 4 & 4 & 4 \\
$\begin{array}{c}(\%) \\
\text { Talkum(\%) }\end{array}$ & 1 & 1 & 1 & 1 \\
$\begin{array}{c}\text { Magnesium } \\
\text { Stearat (\%) }\end{array}$ & 1 & 1 & 1 & 1 \\
Laktosa (g) & ad. & ad. & ad. & ad. \\
\hline
\end{tabular}

pengikat pati kulit Nanas yang berbeda-beda yaitu formula I $4 \%$, formula II $6 \%$, formula III $8 \%$ dan formula IV $10 \%$. Formula granul yang dibuat dapat dilihat di tabel berikut

Tabel 1. Formula Granul

Granul dibuat dengan metode granulasi basah dengan zat aktif yang digunakan sebagai model drug ialah CTM. Semua bahan yang diperlukan baik fase dalam maupun fase luar ditimbang sesuai kebutuhan. Pertama fase dalam dimasukkan satu per satu ke dalam wadah, dimulai dengan memasukkan zat aktif CTM, laktosa dan explotab ke dalam lumpang dan digerus hinggan homogen, kemudian ditambahkan larutan pengikat yaitu pati kulit Nanas sedikit demi sedikit hingga terbentuk massa yang bisa dikepal. Hasil pencampuran awal diayak dengan ayakan mesh No.14 dan dikeringkan dalam oven pada suhu $40^{\circ} \mathrm{C}$ hingga bobot konstan. Granul kering diayak dengan ayakan mesh no. 14, kemudian ditambahkan fase luar yaitu explotab, talkum dan magnesium stearat melalui ayakan, aduk homogen 5 menit, dilakukan evaluasi granul pada keempat formulasi.

\section{Evaluasi Granul}

a. Uji Organoleptik 
Dilihat secara langsung mulai dari bentuk, warna dan bau dari granul yang dihasilkan. Bentuk dan warna yang dihasilkan sedapat mungkin sama antara satu dengan yang lainnya.

b. Uji Kandungan Lembab dan Kadar Air

Pengukuran kelembaban dalam zat padat basah ialah suatu perhitungan berdasarkan bobot kering. Angka ini dianggap sebagai kandungan lembab (moisture content) atau MC. Persyaratannya ialah $2-4 \%$.

$$
\% M C=\frac{\text { bobot granul basah }- \text { bobot granul kering }}{\text { bobot granul kering }} \times 100
$$

Kadar air ditentukan dengan menimbang granul sebelum pengeringan dan sesudah pengeringan. Kadar air dinyatakan sebagai LOD (Lost On Drying) dan ditentukan dengan rumus sebagai berikut :

$$
\% L O D=\frac{\text { bobot granul basah }- \text { bobot granul kering }}{\text { bobot granul basah }} \times 100
$$

\section{c. Uji Waktu Alir dan Sudut Diam}

Uji kecepatan aliran dan sudut istirahat dilakukan dengan menimbang granul sebanyak 100 g lalu dimasukkan ke dalam corong gelas yang lubang bawahnya ditutup dan telah dipasang pada statif dengan ketinggian tertentu dari suatu permukaan yang datar kemudian diratakan. Pada permukaan ini tepat di bagian bawah corong diletakkan kertas grafik sebagai alas, dengan hati-hati, tutup corong dibuka hingga granul meluncur sampai seluruh granul habis. Waktu yang dibutuhkan oleh granul untuk mengalir dicatat, lakukan tiga kali pengulangam. Selanjutnya, tinggi dan diameter lingkaran dasar timbunan granul yang terbentuk diukur dan dicatat. Sudut istirahat dihitung dengam rumus :

$$
\tan \alpha=\frac{2 h}{d}
$$

dimana $: \mathrm{h}=$ tinggi timbunan granul $(\mathrm{cm})$

$\mathrm{d}=$ diameter timbunan granul $(\mathrm{cm})$

d. Uji BJ Sejati

Penentuan bobot jenis sejati dilakukan dengan cara menimbang piknometer $50 \mathrm{~mL}$ yang kosong (a) kemudian diisi dengan parafin cair dan ditimbang kembali (b). Ke dalam piknometer kosong diisi granul kemudian ditimbang (c), ditambahkan parafin cair hingga penuh dan ditimbang kembali (d). Bobot jenis sejati dapat dihitung sebagai berikut:

$$
\begin{aligned}
& \text { BJ cairan pendispersi }=\frac{b-a(\mathrm{gram})}{50(\mathrm{ml})} \\
& \text { BJ sejati }=\frac{(c-a) B J \text { cairan pendispersi }}{(c+b)-(a+d)}
\end{aligned}
$$

e. Uji BJ Nyata, BJ Mampat dan Porositas

Uji BJ nyata dan BJ mampat dilakukan dengan menimbang granul sebanyak $25 \mathrm{~g}$ lalu dimasukkan ke dalam gelas ukur $100 \mathrm{~mL}$ dan dicatat volumenya $\left(\mathrm{V}_{0}\right)$. Kemudian dilakukan pengetukan dengan alat hingga 500 ketukan untuk mendapatkan volume mampatnya. Volume pada ketukan ke-10, ke-50, dan ke-500 diukur sesuai dengan skala yang terdapat pada gelas ukur, lalu dilakukan perhitungan sebagai berikut :

$$
\begin{aligned}
& \text { BJ nyata }=\frac{\text { bobot granul }}{\text { volume awal }} \\
& \text { BJ mampat }=\frac{\text { bobot granul }}{\text { volume mampat }} \\
& \text { Porositas }=1-\left(\frac{\text { BJ mampat }}{\text { BJ se jati }}\right) \times 100 \%
\end{aligned}
$$

\section{HASIL DAN PEMBAHASAN}

\section{Klasifikasi Tumbuhan}

Klasifikasi tumbuhan dilakukan di Program Studi Biologi Fakultas Matematika dan Ilmu Pengetahuan Alam Universitas Sam Ratulangi dan dinyatakan bahwa 


\begin{tabular}{cccc}
\hline Formulasi & Bentuk & Warna & Bau \\
\hline I & $\begin{array}{c}\text { Bulat, } \\
\text { tidak } \\
\text { merata } \\
\text { Bulat, } \\
\text { tidak } \\
\text { merata }\end{array}$ & Putih & $\begin{array}{c}\text { Khas Pati } \\
\text { Kulit Nanas }\end{array}$ \\
II & Bulat & Putih & $\begin{array}{c}\text { Khas Pati } \\
\text { Kulit Nanas }\end{array}$ \\
III & Kulit Nanas \\
IV & Bulat & Putih & $\begin{array}{c}\text { Khas Pati } \\
\text { Kulit Nanas }\end{array}$ \\
\hline $\begin{array}{l}\text { tumbuhan } \\
\text { penelitian } \\
\text { merr }\end{array}$ & ini digunakan kulitnya dalam \\
ialah & Ananas & comosus (l.)
\end{tabular}

\section{Pembuatan Pati dari Kulit Nanas}

Sebanyak $3 \quad \mathrm{~kg}$ kulit Nanas dibersihkan dan dirajang tipis-tipis dengan pisau, direndam dengan larutan garam dapur, dikeringkan dan diblender hingga menghasilkan serbuk kulit Nanas. Serbuk

\begin{tabular}{ll}
\hline Bahan & Hasil \\
\hline
\end{tabular}

Pati Kulit Nanas + akuades + iodium

kulit Nanas diendapkan dalam air dalam wadah kaca kemudian dibilas sebanyak tiga kali dengan akuades dan dikeringkan dalam oven dengan suhu $40^{\circ} \mathrm{C}$. Pati kulit Nanas yang dihasilkan ialah 63,281 gram.

\section{Uji Kualitatif Pati}

Sebanyak 2 gram pati kulit Nanas ditambahkan akuades secukupnya, ketika ditetesi larutan iodium 5-10 larutan membentuk warna ungu kehitaman

Tabel 2. Uji Kualitatif Pati

\section{Uji Organoleptik}

Uji ini dilakukan dengan melihat penampilan umum granul meliputi bentuk, warna dan bau dari granul tersebut.

\section{Tabel 3. Uji Organoleptik}

\section{Kandungan Lembab dan Kadar Air}

Pengukuran kelembaban dalam zat padat basah ialah suatu perhitungan berdasarkan bobot kering. Angka ini dianggap sebagai kandungan lembab (moisture content) atau MC. Kadar air yaitu suatu pernyataan kadar kelembaban berdasarkan berat basah.

Tabel 4. Kandungan Lembab

\begin{tabular}{cc}
\hline Formulasi & Hasil (\%) \\
\hline I & 29 \\
II & 33,3 \\
III & 20,4 \\
IV & 26,7 \\
\hline
\end{tabular}

Tabel 5. Kadar Air

\begin{tabular}{cc}
\hline Formulasi & Hasil (\%) \\
\hline I & 22,17 \\
II & 25 \\
III & 16,69 \\
IV & 21,08
\end{tabular}

\section{Uji Waktu Alir}

Uji ini dilakukan dengan cara menimbang 100 gram granul dan dialirkan melalui sebuah corong dan di bawah corong diletakkan kertas grafik dengan dilakukan 3 kali pengulangan. Jika waktu alir dari 100 gram granul $\leq 10$ detik, maka granul tersebut memiliki kecepatan alir yang baik.

Tabel 6. Uji Waktu Alir

\begin{tabular}{|c|c|c|c|c|c|}
\hline \multirow{2}{*}{$\begin{array}{c}\text { Formulas } \\
i\end{array}$} & \multicolumn{3}{|c|}{$\begin{array}{c}\text { Waktu Alir } \\
\text { (detik) }\end{array}$} & \multirow{2}{*}{$\begin{array}{l}\text { Rata- } \\
\text { Rata } \\
\text { (deti } \\
\text { k) }\end{array}$} & \multirow{2}{*}{$\begin{array}{c}\text { Keteral } \\
\text { gan }\end{array}$} \\
\hline & I & II & III & & \\
\hline I & 5.66 & 5.45 & 5.60 & 5.57 & \\
\hline
\end{tabular}

$\begin{array}{cccccc}\text { II } & 5.32 & 5.24 & 5.75 & 5.43 & \begin{array}{l}\text { Memenu } \\ \text { hi syara207 }\end{array} \\ \text { III } & 5.01 & 5.60 & 5.32 & 5.31 & \begin{array}{l}\text { Memenu } \\ \text { hi syarat }\end{array}\end{array}$




\begin{tabular}{cccc}
\hline Formulasi & $\begin{array}{c}\text { Bobot } \\
\text { Granul } \\
(\mathrm{g})\end{array}$ & $\begin{array}{c}\text { Volume } \\
\text { Awal } \\
(\mathrm{ml})\end{array}$ & $\begin{array}{c}\text { BJ Nyata } \\
(\mathrm{g} / \mathrm{ml})\end{array}$ \\
\hline I & 25 & 53 & 0,471 \\
II & 25 & 50 & 0,5 \\
III & 25 & 57 & 0,438 \\
IV & 25 & 57 & 0,438 \\
\hline
\end{tabular}

\section{BJ Nyata}

Uji ini dilakukan dengan cara menimbang 25 gram granul dan dimasukkan ke dalam gelas ukur $100 \mathrm{ml}$ dan dicatat volumenya sebagai volume awal $\left(\mathrm{V}_{0}\right)$, kemudian dihitung bobot jenis nyata dengan rumus bobot granul per volume awal.

Tabel 9. BJ Nyata

\section{Uji Sudut}

Diam

Uji

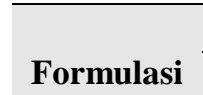

ini dilakukan

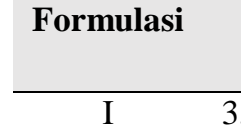

dengan

mengukur

II

II

II

h (tinggi)

IV

diameter dari timbunan granul yang terbentuk

\begin{tabular}{|c|c|c|c|c|c|}
\hline \multicolumn{3}{|c|}{ d (diameter) } & \multicolumn{2}{|c|}{ Rata-rata } & \multirow{2}{*}{$\begin{array}{c}\text { Sudut } \\
\text { Diam } \\
\left({ }^{\circ}\right)\end{array}$} \\
\hline 1 & 2 & 3 & h & d & \\
\hline 13,50 & 14,00 & 14,00 & 3,6 & 13,83 & 28 \\
\hline 14,00 & 14,00 & 13,50 & 4,4 & 13,83 & 33 \\
\hline 13,70 & 14,00 & 13,70 & 4,3 & 13,80 & 32 \\
\hline 13,90 & 14,00 & 13,50 & 4,1 & 13,80 & 31 \\
\hline
\end{tabular}

BJ
Mampat
dan
Porositas
Uji ini
dilakukan
dengan

pengukuran bobot granul per volume granul setelah dimampatkan. Hasil uji BJ Mampat Tabel 7. Uji Sudut Riamporositas dapat dilihat pada tabel berikut

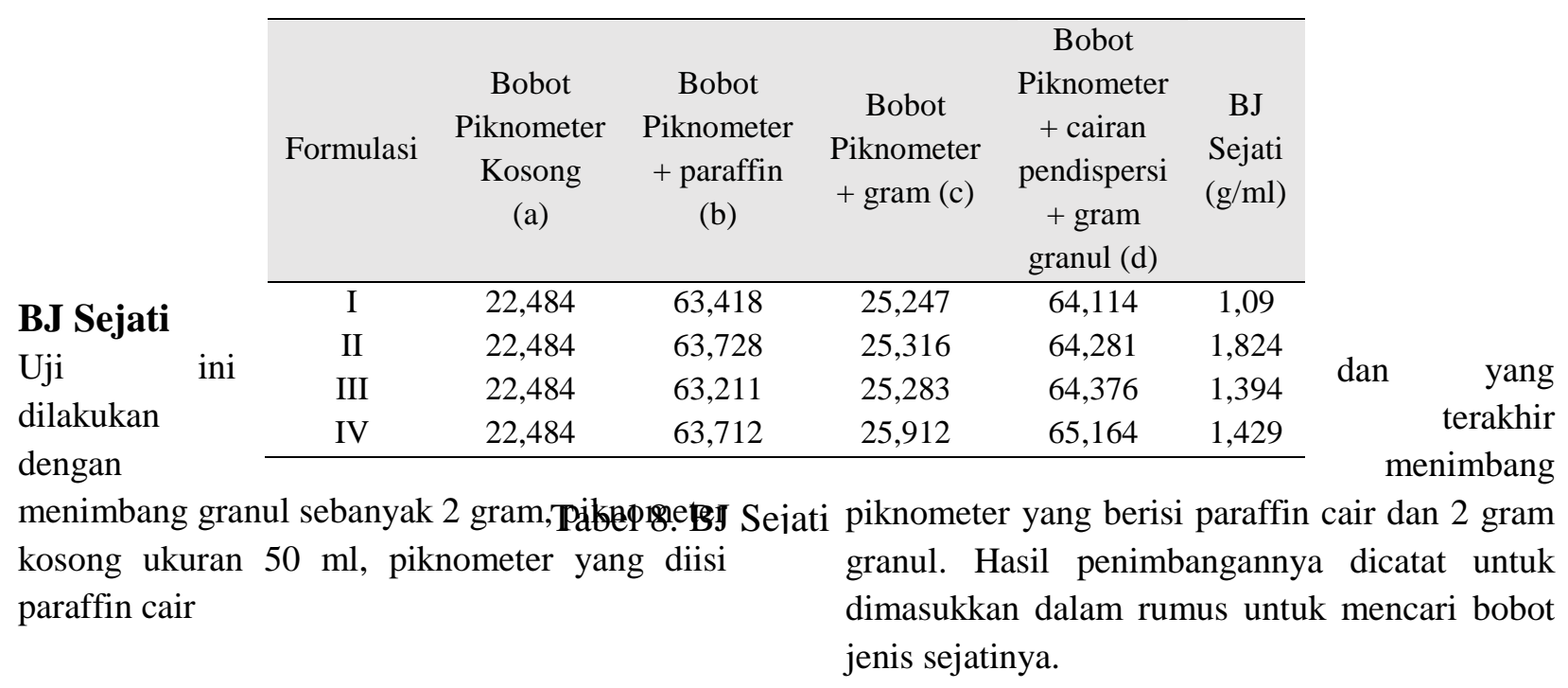




\section{Pembahasan}

Penelitian ini menggunakan sampel yang berasal dari kulit Nanas yang dimanfaatkan sebagai salah satu komponen bahan tambahan yaitu sebagai pengikat pada sediaan granul. Pati kulit Nanas dibuat dengan empat konsentrasi yaitu 4\%, 6\%, $8 \%$ dan $10 \%$. Penggunaan konsentrasi tersebut didasarkan pada konsentrasi pati secara umum yang sering digunakan sebagai bahan pengikat yaitu pada konsentrasi 410\% (Rowe dkk, 2009).

Pengujian kualitatif pati dilakukan dengan uji iodium. Hasil pengujian menunjukkan perubahan warna menjadi ungu kehitaman yang menandakan bahwa dalam kulit Nanas terdapat kandungan pati yaitu amilopektin (Mustaqim, 2012).

\section{Uji Oranoleptik}

Hasil Pengujian organoleptik dari keempat formulasi memiliki warna yang sama yaitu putih dan bau yang sama yaitu berbau khas kulit nanas. Bentuk dari formulasi I dan II berbeda dengan bentuk pada formulasi III dan IV, pada formulasi I dan II bentuk granul bulat namun tidak merata, hal tersebut disebabkan oleh perbedaan konsentrasi bahan pengikat dari masing-masing formulasi, semakin tinggi konsentrasi bahan pengikat maka ukuran granul akan lebih kompak dengan ukuran partikel yang lebih besar (Anonim, 1995).

\section{Kandungan Lembab dan Kadar Air}

Hasil uji kandungan lembab dari formulasi I sampai IV 29\%, 33\%, 20,4\%, dan 26,7\%. Evaluasi kadar lembab granul penting untuk dilakukan karena kelembapan granul dapat mempengaruhi atau menjadi penyebab dari permasalahn pencetakan tablet. Persyaratan kandungan lembab granul yaitu 2-4\% (Lachman dkk, 1990). Penelitian yang dilakukan oleh Sapri, dkk (2012) yang menggunakn pati biji Campedak sebagai bahan pengikat pada konsentrasi 6\%, $8 \%$ dan 10\% memberikan hasil kandungan lembab secara berturutturut $1,78 \%, 2,03 \%$ dan 2,61\%, pada konsentrasi $8 \%$ dan $10 \%$ menghasilkan kandungan lembab yang cukup baik karena memenuhi persyaratan kandungan lembab. Hasil tersebut menunjukkan bahwa uji kandungan lembab yang dihasilkan dengan penggunaan pati kulit Nanas sebagai bahan pengikat sangat besar dikarenakan rendahnya suhu pengeringan granul dan tingginya kadar air dalam granul sehingga tidak memenuhi persyaratan (Ardiani, 2012). Kandungan lembab yang terlalu rendah menyebabkan granul akan menjadi terlalu rapuh dan mudah hancur, sedangkan kandungan lembab yang terlalu tinggi dapat menyebabkan granul akan menjadi terlalu basah dan mudah menempel (Siregar dan Wikarsa, 2010).

Hasil kadar air dari keempat formula I-IV yaitu 22,17\%, 25\%, 16,69\%, 21,08\%. Kadar air yang terlalu tinggi dapat meningkatkan gaya kohesi antar partikel yang dapat menyebabkan granul tidak dapat mengalir dengan baik, akibatnya akan 
berpengaruh pada pengisian ruang cetak tablet. Penelitian oleh Haflah, dkk (2012) yang menggunakan pati biji Asam Jawa sebagai bahan pengikat memberikan hasil kandungan lembab pada keempat formulasi yang dibuat berkisar 14,74\%-21,57\%. Hasil ini menunjukkan bahwa kadar air pada granul dengan bahan pengikat pati kulit Nanas tidak memenuhi persyaratan kadar air granul yaitu 2-4\%. Pengukuran kadar air dipengaruhi juag oleh suhu pengeringan, semakin tinggi suhu pengeringan granul maka kadar airnya makin kecil, sebaliknya semakin rendah suhu pengeringan granul maka kadar airnya semakin besar (Ardiani, 2012).

\section{Waktu Alir}

Hasil uji waktu alir dari keempat formulasi memiliki waktu alir yang berbedabeda yaitu 5.57 detik untuk formulasi 1, 5.43 detik formulasi 2, 5.31 detik formulasi 3 dan 5.04 detik untuk formulasi 4. Sifat aliran ini dipengaruhi oleh bentuk partikel, ukuran partikel dan kadar air. Sifat aliran dapat diperbaiki melalui penambahan bahan pelicin yang menurunkan gesekan antar partikel, makin besar konsentrasi bahan pengikat yang digunakan, maka makin cepat waktu alirnya, hal ini disebabkan karena semakin tinggi konsentrasi pengikat maka massa granul yang dihasilkan semakin baik, yaitu memberikan bentuk granul yang bulat atau tidak beraturan (hampir bulat) dengan permukaan yang halus sehingga mudah untuk mengalir. Pengujian laju daya alir dilakukan untuk menjamin keseragaman pengisian ke dalam cetakan untuk pembuatan tablet (Sapri dkk, 2012). Hasil tersebut menunjukkan bahwa keempat formulasi memenuhi persyaratan dimana saat 100 gram granul dialirkan dari setiap formulasi hasilnya $\leq 10$ detik (Lachman dkk, 1990).

\section{Sudut Diam}

Pengujian sudut diam berhubungan dengan pengujian waktu alir. Berdasarkan hasil yang diperoleh sudut diam dari masing-masing formula berturut-turut yaitu $28^{\circ}, 33^{\circ}, 32^{\circ}$, dan $31^{\circ}$. Penelitian menurut Wahyuni, dkk (2016) yang mengggunakan pati Umbi Tire sebagai bahan pengikat pada konsetrasi $10 \%$ memiliki sudut diam $30^{\circ}$, hasil tersebut menunjukkan bahwa bahan pengikat dengan pati kulit Nanas menghasilkan sudut diam lebih besar dibandingkan dengan pengikat pati Umbi Tire. Sudut diam yang terbentuk dipengaruhi oleh ukuran partikel, semakin kecil ukuran partikel maka kohesivitas partikel makin tinggi yang akan mengurangi kecepatan alirnya sehingga sudut diam yang terbentuk semakin besar (Lee, 2004). Sifat alir granul dinyatakan mengalir dengan baik apabila membentuk sudut $25^{\circ}-40^{\circ}$ (Wadke dan Jacobson, 1989), berdasarkan hal tersebut maka disimpulkan bahwa granul dari keempat formula mengalir.

\section{BJ Sejati}

Perhitungan bobot jenis sejati dilakukan untuk mengetahui apakah granul mengapung, melayang, atau tenggelam dalam suatu pelarut. Pelarut yang digunakan pada penelitian ini yaitu paraffin cair karena paraffin cair ialah pelarut yang tidak dapat melarutkan granul yang dibuat sehingga granul tersebut bisa dilihat apakah mengapung, melayang atau tenggelam. Hasil yang diperoleh dari keempat formulasi yaitu $1,09 \mathrm{~g} / \mathrm{ml}, 1,824 \mathrm{~g} / \mathrm{ml}, 1,394 \mathrm{~g} / \mathrm{ml}$, dan 1,429 $\mathrm{g} / \mathrm{ml}$. Hasil tersebut menunjukkan bahwa 
keempat formulasi tenggelam karena bobot jenis sejati yang didapatkan lebih besar dari bobot jenis air yaitu $1 \mathrm{~g} / \mathrm{ml}$. Penelitian menurut Haflah, dkk (2012) yang menggunakan pati biji Asam Jawa sebagai bahan pengikat pada konsentrasi $10 \%$ memperoleh bobot jenis sejati $1,499 \mathrm{~g} / \mathrm{ml}$. Perbedaan nilai bobot jenis sejati yang diperoleh dari masing-masing formulasi disebabkan oleh perbedaan jumlah ruang kosong intra partikel. Semakin tinggi bobot jenis sejati yang diperoleh maka makin banyak ruang intra partikelnya (Haflah, dkk 2012).

\section{BJ Nyata, BJ Mampat dan Porositas}

Bobot jenis nyata dari keempat formulasi berturut-turut yaitu $0,471 \mathrm{~g} / \mathrm{ml}$, $0,5 \mathrm{~g} / \mathrm{ml}, 0,438 \mathrm{~g} / \mathrm{ml}$ dan $0,438 \mathrm{~g} / \mathrm{ml}$, semakin besar konsentrasi bahan pengikat pati kulit Nanas yang digunakan maka semaikn besar juga ukuran partikel sebaliknya semakin kecil konsentrasi bahan pengikat pati kulit Nanas yang digunakan maka ukuran partikelnya juga kecil. Partikel yang besar menghasilkan kerapatan yang kecil, sedangkan partikel dengan ukuran yang lebih kecil akan membentuk massa dengan kerapatan yang lebih besar (Gordon dkk, 1989). Penelitian menurut Elisabeth, dkk (2018) yang menggunakan pati kulit Pisang Goroho sebagai bahan pengikat menghasilkan bobot jenis nyata pada konsentrasi $6 \%, 8 \%$ dan $10 \%$ secara berturut-turut $0,45 \mathrm{~g} / \mathrm{ml}, 0,44 \mathrm{~g} / \mathrm{ml}$, dan 0,42 $\mathrm{g} / \mathrm{ml}$, hasil tersebut menunjukkan bahwa penggunaan pati kulit Pisang Goroho dan pati kulit Nanas sebagai bahan pengikat menghasilkan bobot jenis nyata yang lebih kecil dan ukuran partikel yang besar. Bobot jenis mampat memberikan hasil yaitu 0,555 $\mathrm{g} / \mathrm{ml}, 0,595 \mathrm{~g} / \mathrm{ml}, 0,5 \mathrm{~g} / \mathrm{ml}$ dan $0,481 \mathrm{~g} / \mathrm{ml}$. Tujuan dari perhitungan bobot jenis mampat yaitu untuk mengetahui kompresibilitas granul yang dapat memenuhi kekerasan dan kerapuhan tablet. Bobot jenis mampat tergantung pada bentuk partikel, bentuk granul yang seragam akan memudahkan granul menjadi bentuk mampatnya karena rongga antar granul akan semakin sedikit. Bila ukuran granul bertambah besar, kecepatan bulk menurun. Granul kecil lebih dapat membentuk massa yang kompak daripada granul besar (Lachman dkk, 1990). Hasil uji porositas dari keempat formulasi yaitu 49,1\%, 67,4\%, 64,2\%, dan 66,4\%. Nilai ini memenuhi range porositas granul pada umumnya yaitu berkisar 10 - 70\% (Lachman dkk, 1990). Porositas atau keadaan yang berongga-rongga ini dapat digunakan untuk menjelaskan tingkat kekuatan suatu serbuk. Peningkatan nilai porositas akan meningkatkan laju disolusi dan menurunkan waktu disintegrasi (Ennis, 2005). Porositas yang tinggi menunjukkan banyaknya ruang kosong yang dapat terisi oleh serbuk halus dalam tablet (Voight, 1995). Jika granul memiliki prorositas yang cukup besar maka kemungkinan tablet yang akan dihasilkan akan terlihat rapuh dan mudah pecah (Fransina, 2010). Rendahnya porositas menyebabkan tingginya kekerasan tablet yang akan dihasilkan.

\section{KESIMPULAN}

1. Pati kulit Nanas tidak dapat digunakan sebagai bahan pengikat pada sediaan granul CTM.

2. Hasil evaluasi dari empat formulasi sediaan granul CTM menggunakan bahan pengikat pati kulit Nanas memberikan 
hasil yang sesuai persyaratan padaevaluasi uji waktu alir, uji organoleptis, uji sudut diam, uji bobot jenis sejati, uji bobot jenis nyata, mampat dan porositas, tetapi tidak memenuhi persyaratan pada uji kandungan lembab dan kadar air.

\section{SARAN}

Perlu mengoptimalkan proses pembuatan pati kulit Nanas, sehingga menghasilkan pati kulit Nanas yang baik dan selanjutnya dapat dikembangkan sebagai bahan tambahan dalam sediaan farmasi.

\section{DAFTAR PUSTAKA}

Anonim. 1995. Farmakope Indonesia Edisi 4. Departemen Kesehatan Republik Indonesia, Jakarta

Ardiani, P.W. 2012. Perbandingan Variasi Suhu Pengeringan Granul Terhadap Kadar Air dan Sifat Fisik Tablet Parasetamol. Universitas Sebelas Maret, Surakarta

Elisabeth, V., Yamlean, P.V.Y., Supriati, H. 2018. Formulasi Sediaan Granul dengan Bahan Pengikat Pati Kulit Pisang Goroho dan Pengaruhnya terhadap Sifat Fisik Granul. Jurnal Ilmiah Farmasi UNSRAT. 7(4) : 1-11

Ennis, B.J. 2005. Handbook of Pharmaceutical Granulation Technology. Taylor and Francis, Singapur

Fransina, E.G. 2010. Karakterisasi Granul Parasetamol yang menggunakan Natrium Alginat sebagai Desintegran. 5(3) : 289-302

Gordon, R.E., Rosanske, T.W., Foner, D.E., Anderson, N.R., Banker, G.S. 1989. Granulation technology and tablet characterization. Marcel Dekker, New York

Haflah., Hasyim, M., Taebe, B. 2012. Penggunaan Pati Biji Asam Jawa (Tamarindus indica L.) Sebagai Bahan Pengikat pada Tablet Parasetamol Secara Granulasi Basah. Jurnal Of Pharmtech Research. 10(3) : 799-814

Jufri, M. R., Dewi, A., Ridwan., Firli. 2006. Studi kemampuan pati biji durian sebagai bahan pengikat dalam tablet ketoprofen secara granulasi basah. Majalah Ilmu Kefarmasian. 3(2): 7886

Lachman, L., Herbert, A. L., Joseph, L. K. 1990. Teori dan Praktek Industri Farmasi Edisi III. Penerbit Universitas Indonesia, Jakarta

Lee, R. I. 2004. Effervescent Tablets: Key Facts About A Unique, Effective Dossage Form. CSC Publishing, Amerika

Mustaqim, M. 2012. Uji Identifikasi Karbohidrat. Pustaka Baru Press, Yogyakarta

Pawar, P. D. 2015. Review on Pharmaceutical Excipients. American Journal of Pharmacy \& Health Research. 5(3) : 53-57

Rahmawati, A. 2010. Pemanfaatan Limbah Kulit Ubi Kayu (Manihot utilissima Pohl.) dan Kulit Nanas (Ananas comosus L.) Pada Produksi Bioetanol Menggunakan Aspergillus niger. Jurnal Biologi Surakarta. 6(3) : 2229

Rowe, R.C., Sheskey, P.J., Quin, M.E. 2009. Handbook Of Pharmaceutical Excipients $6^{\text {th }} \quad E d$. The Pharmaceutical Press, London. 
Sapri., Dedi, S., Rizki K. 2012. Pengaruh Penggunaan Pati Biji Cempedak (Arthocarpus Champeden Lour) sebagai Bahan Pengikat terhadap Sifat Fisik Tablet Parasetamol secara Granulasi Basah. J. Trop. Pharm. Chem. 2(1): 47-61

Sidharta, F.M. 1989. Pemanfaatan Limbah Pengolahan Nanas (Ananas comosuss L. Merr) Sebagai Bahan Baku Pembuatan. Jurnal Riset Industri. 5(1) : 77-89

Siregar, C.J.P., Wikarsa, S. 2010. Teknologi Farmasi Sediaan Tablet DasarDasar Praktis. Penerbit Buku Kedokteran EGC, Jakarta

Sugiyono, S., Afriliana, H.S., Windriati, Y.N. 2013. Pengaruh Penggunaan Amilum Biji Durian (Durio Zibethinus L.) sebagai Bahan Penghancur yang ditambahkan secara internal- Eksternal Terhadap Sifat Fisik dan Kimia Tablet Ibuprofen. Jurnal Fakultas Farmasi Unwahas Semarang. 10(1):31-5

Voigt. 1995. Buku AjarTeknologi Farmasi. UGM Press, Yogyakarta

Wadke, H.A., Jacobson, H. 1989. Preformulation Testing and Pharmaceutical Dosage Form : Tablet. Marcel Dekker Inc, New York

Wahyuni., Ningsi, S., Armisman, A. 2016. Pemanfaatan Pati Umbi Tire (Amorphophalus onchopillus) Sebagai Bahan Pengikat Tablet Parasetamol dengan Metode Granulasi Basah. Jurnal Ilmiah Farmasi Farmasyifa. 1(1) : 53-61 